\title{
Stenotrophomonas daejeonensis sp. nov., isolated from sewage
}

\author{
Correspondence \\ Myungjin Lee \\ mgeneli@nate.com \\ Leonid N. Ten \\ Iten@kier.re.kr
}

\author{
Myungjin Lee, ${ }^{1}$ Sung-Geun Woo, ${ }^{1,2}$ Myoungsoo Chae, ${ }^{1}$ Min-Cheol Shin, ${ }^{1}$ \\ Hae-Min Jung ${ }^{3}$ and Leonid N. Ten ${ }^{4}$
${ }^{1}$ Research and Development Division, H-Plus Eco Ltd, BVC \#301, KRIBB, Eoeun-dong, Yuseong- gu, Daejeon 305-333, Republic of Korea
${ }^{2}$ School of Civil and Environmental Engineering, Yonsei University, Seoul 120-749, Republic of Korea Guseong-dong, Yuseong-gu, Daejeon 305-701, Republic of Korea
${ }^{4}$ Bioenergy Research Center, Korea Institute of Energy Research, 102, Gajeong-ro, Yuseong-gu, Daejeon 305-343, Republic of Korea \\ ${ }^{3}$ Department of Biological Sciences, Korea Advanced Institute of Science and Technology, 373-1,
}

\begin{abstract}
A Gram-stain-negative, motile, aerobic bacterial strain, designated $\mathrm{MJO}^{\top}$, was isolated from sewage and was characterized taxonomically by using a polyphasic approach. Comparative 16S rRNA gene sequence analysis showed that strain $\mathrm{MJO}^{\top}$ belongs to the family

Xanthomonadaceae, class Gammaproteobacteria, and was related most closely to Stenotrophomonas acidaminiphila AMX $19^{\top}$ (97.9\% sequence similarity), Stenotrophomonas humi R-32729 ${ }^{\top}$ (97.1\%), Stenotrophomonas nitritireducens $\mathrm{L}^{\top}{ }^{\top}(96.9 \%)$, Stenotrophomonas maltophila ATCC $13637^{\top}$ (96.8\%) and Stenotrophomonas terrae R-32768 ${ }^{\top}$ (96.7\%). The G+C content of the genomic DNA of strain $\mathrm{MJO3}^{\top}$ was $64.7 \mathrm{~mol} \%$. The detection of a quinone system with ubiquinone $\mathrm{Q}-8$ as the predominant component and a fatty acid profile with iso- $\mathrm{C}_{15: 0}$, iso- $\mathrm{C}_{11: 0}$, iso- $\mathrm{C}_{14: 0}$, iso- $\mathrm{C}_{17: 1} \omega 9 \mathrm{c}$, iso- $\mathrm{C}_{11: 0} 3-\mathrm{OH}$ and iso- $\mathrm{C}_{13: 0} 3-\mathrm{OH}$ as major components supported the affiliation of strain $\mathrm{MJO}^{\top}$ to the genus Stenotrophomonas. However, levels of DNA-DNA relatedness between strain $\mathrm{MJO}^{\top}$ and the type strains of five closely related species of the genus Stenotrophomonas ranged from 11 to $34 \%$, showing clearly that the isolate represents a novel genospecies. Strain $\mathrm{MJO}^{\top}$ could be differentiated clearly from its phylogenetic neighbours on the basis of several phenotypic, genotypic and chemotaxonomic features.

Therefore, strain $\mathrm{MJO3}^{\top}$ is considered to represent a novel species of the genus

Stenotrophomonas, for which the name Stenotrophomonas daejeonensis sp. nov. is proposed. The type strain is $\mathrm{MJO3}^{\top}\left(=\mathrm{KCTC} 22451^{\top}=\mathrm{JCM} 16244^{\top}\right)$.
\end{abstract}

The genus Stenotrophomonas, a member of the family Xanthomonadaceae, class Gammaproteobacteria, was created in 1993 with the reclassification of Xanthomonas maltophila as Stenotrophomonas maltophila (Palleroni \& Bradbury, 1993). At the time of writing, the genus comprises eight recognized species: S. maltophila (Palleroni \& Bradbury, 1993), S. nitritireducens (Finkmann et al., 2000), S. acidaminiphila (Assih et al., 2002), S. rhizophila (Wolf et al., 2002), S. koreensis (Yang et al., 2006), S. humi (Heylen et al., 2007), S. terrae (Heylen et al., 2007) and S. ginsengisoli (Kim et al., 2010). Members of the genus Stenotrophomonas have the following characteristics: they are Gram-negative, non-spore-forming, motile or non-motile rods, are positive

Abbreviation: HE-cellulose, hydroxyethylcellulose.

The GenBank/EMBL/DDBJ accession number for the 16S rRNA gene sequence of strain $\mathrm{MJO3}^{\mathrm{T}}$ is GQ241320. for catalase and glucose fermentation, contain iso- $\mathrm{C}_{15: 0}$ as the predominant cellular fatty acid and have DNA G $+C$ contents in the range $64.0-69.1 \mathrm{~mol} \%$. Species of the genus Stenotrophomonas are common inhabitants of a wide variety of natural and artificial environments and geographical regions. In particular, the type strains of the abovementioned species were isolated from soil, compost, plant rhizosphere, an anaerobic sludge blanket reactor, an ammonia-supplied bio-filter and the pleural fluid of a patient with oral carcinoma. During the course of screening micro-organisms from sewage, a Gram-stain-negative, rodshaped bacterial strain, designated $\mathrm{MJ}^{0} 3^{\mathrm{T}}$, was isolated. On the basis of $16 \mathrm{~S}$ rRNA gene sequence analysis, this isolate was considered to be a Stenotrophomonas-like strain. To determine its exact taxonomic position, strain $\mathrm{MJ} 03^{\mathrm{T}}$ was subjected to a detailed investigation by using a polyphasic taxonomic approach, including genotypic, chemotaxonomic 
and classical phenotypic analyses. These results indicate that strain $\mathrm{MJ} 3^{\mathrm{T}}$ should be placed in the genus Stenotrophomonas as a representative of a novel species.

Strain $\mathrm{MJ} 3^{\mathrm{T}}$ was isolated from a sewage water sample collected from the inflow region of a municipal sewage treatment plant located in Daejeon, South Korea. The sample was a cloudy liquid with a $\mathrm{pH}$ of 7.2 and a temperature of $22{ }^{\circ} \mathrm{C}$. It mainly comprised water $(>99.9 \%)$ together with relatively small concentrations of suspended $\left(150 \mathrm{mg} \mathrm{l}^{-1}\right)$ and dissolved $\left(230 \mathrm{mg} \mathrm{l}^{-1}\right)$ organic and inorganic solids. The sample was suspended and spread on R2A agar plates (Difco) after being serially diluted with $50 \mathrm{mM}$ phosphate buffer ( $\mathrm{pH}$ 7.0). The plates were incubated at $30{ }^{\circ} \mathrm{C}$ for 2 weeks. Single colonies on the plates were purified by transferring them onto fresh plates and incubating them again under the same conditions. The isolate was routinely cultured on R2A agar at $30{ }^{\circ} \mathrm{C}$ and was maintained as a glycerol suspension $(20 \%$, w/v) at $-70{ }^{\circ}$ C. S. acidaminiphila KACC $11356^{\mathrm{T}}$, S. humi DSM $18929^{\mathrm{T}}$, S. maltophilia KCTC $1773^{\mathrm{T}}$, S. nitritireducens KACC $10891^{\mathrm{T}}$ and S. terrae DSM $18941^{\mathrm{T}}$ were used as reference strains for DNA-DNA hybridization and other experiments.

The Gram reaction was determined by using a Gram-stain kit (Difco) according to the manufacturer's instructions. Cell morphology and motility were observed under a Nikon light microscope $(\times 1000$ magnification) by using the hanging-drop technique with cells grown for 2 days at $30{ }^{\circ} \mathrm{C}$ on R2A agar. Endospores were stained negatively by using the method of Cappuccino \& Sherman (2002) and were observed by light microscopy. Tests for anaerobic growth were performed in serum bottles containing R2A broth supplemented with thioglycolate $\left(1 \mathrm{~g} \mathrm{l}^{-1}\right)$ under a nitrogen atmosphere. Catalase and oxidase tests were performed as outlined by Cappuccino \& Sherman (2002). Assimilation of single carbon sources, enzyme activities, acid production from substrates and other physiological characteristics were determined with the API ID 32 GN $\left(48 \mathrm{~h}, 30^{\circ} \mathrm{C}\right)$, API ZYM $\left(4 \mathrm{~h}, 30^{\circ} \mathrm{C}\right)$, API $20 \mathrm{NE}(48 \mathrm{~h}$, $\left.30{ }^{\circ} \mathrm{C}\right)$ and API $50 \mathrm{CHB}\left(48 \mathrm{~h}, 30^{\circ} \mathrm{C}\right)$ galleries according to the manufacturer's instructions (bioMérieux). Acid production from $\mathrm{N}$-acetylglucosamine, aesculin and glycogen was additionally determined by using $\mathrm{O} / \mathrm{F}$ basal medium containing bromothymol blue (Atlas, 1993) supplemented with $1 \%$ carbohydrate (soft-agar stabs with a sterile mineral oil overlay). Reduction of nitrate and nitrite was determined by using serum bottles $(25 \mathrm{ml})$ containing $12 \mathrm{ml} \mathrm{R} 2 \mathrm{~A}$ broth supplemented with $\mathrm{KNO}_{3}(10 \mathrm{mM})$ and $\mathrm{NaNO}_{2} \quad(10 \mathrm{mM})$, respectively (Assih et al., 2002). Reduction of nitrate and nitrite was monitored by ion chromatography on a model 790 personal chromatograph (Metrohm) equipped with a conductivity detector and an anion exchange column (Metrosep Anion Supp 4; Metrohm). Hydrolysis of casein was examined on nutrient agar supplemented with $1.5 \%$ dry skimmed milk (Tindall et al., 2007). Chitinase activity was tested by using R2A agar medium supplemented with colloidal chitin $\left(4 \mathrm{~g} \mathrm{l}^{-1}\right.$;
Hsu \& Lockwood, 1975). Hydrolysis of starch was tested on nutrient agar (Difco) plates supplemented with soluble starch $\left(10 \mathrm{~g}^{-1}\right)$. Starch hydrolysis was detected by flooding the plates with iodine solution (Tindall et al., 2007). The test for degradation of DNA [DNase agar (Scharlau), with DNase activity detected by flooding plates with $1 \mathrm{M}$ $\mathrm{HCl}$ ] was performed according to Collins \& Lyne (1984). Hydrolysis of xylan and hydroxyethylcellulose (HE-cellulose) was determined with a nutrient agar medium supplemented with a mixture of chromogenic substrates (xylan-red and HE-cellulose-blue), as described previously (Ten et al., 2004). Biochemical tests for aesculin hydrolysis, indole production (method 1), gelatin hydrolysis (method 2 ), the Voges-Proskauer reaction, $\mathrm{H}_{2} \mathrm{~S}$ production from thiosulfate (method 1), hydrolysis of Tween 80 , and acid phosphatase and alkaline phosphatase activities were performed according to standard methods as described by Tindall et al. (2007). Growth at 10, 15, 20, 25, 30, 37, 42 and $45{ }^{\circ} \mathrm{C}$ was assessed on R2A agar, nutrient agar, LuriaBertani (LB) agar, trypticase soy agar (TSA; Difco) and MacConkey agar (Difco) after 5 days of incubation. Salt tolerance was tested on R2A agar medium supplemented with $1-5 \%(w / v) ~ N a C l$ after incubation for up to 5 days. Growth at pH 5.0-11.0 (at intervals of $0.5 \mathrm{pH}$ units) was assessed after incubation for up 5 days at $30{ }^{\circ} \mathrm{C}$. The effect of $\mathrm{pH}$ on growth was determined in LB broth media using four different buffers (final concentration, $50 \mathrm{mM}$ ): sodium acetate buffer (for $\mathrm{pH}$ 5.0-5.5), potassium phosphate buffer (for $\mathrm{pH}$ 6.0-8.0), $\mathrm{Na}_{2} \mathrm{CO}_{3} / \mathrm{NaHCO}_{3}$ buffer (for $\mathrm{pH} 8.5-10.0$ ) and $\mathrm{Na}_{2} \mathrm{HPO}_{4} / \mathrm{NaOH}$ buffer (for pH 10.5-11.0).

For phylogenetic analysis of strain $\mathrm{MJ} 03^{\mathrm{T}}$, genomic DNA was extracted by using a commercial genomic DNAextraction kit (Solgent), and PCR-mediated amplification of the 16S rRNA gene and sequencing of the purified PCR product were carried out according to Kim et al. (2005). Full sequences of the 16S rRNA gene were compiled by using SeqMan software (DNASTAR). The 16S rRNA gene sequences of related taxa were obtained from the GenBank database. Multiple alignments were performed by using the program CLUSTAL X (Thompson et al., 1997). Gaps were edited in the BioEdit program (Hall, 1999). Evolutionary distances were calculated by using the Kimura twoparameter model (Kimura, 1983). Phylogenetic trees were generated by using the neighbour-joining (Saitou \& Nei, 1987) and maximum-parsimony (Fitch, 1971) algorithms from MEGA4 (Tamura et al., 2007) and the maximumlikelihood (Felsenstein, 1981) method from PHYLIP, version 3.69 (Felsenstein, 2009), with bootstrap values based on 1000 replications (Felsenstein, 1985).

For determination of chromosomal DNA G + C content, the genomic DNA of strain $\mathrm{MJ03}^{\mathrm{T}}$ was extracted and purified as described by Moore \& Dowhan (1995) and degraded enzymically into nucleosides; the DNA G $+\mathrm{C}$ content was determined as described by Mesbah et al. (1989) by using reversed-phase HPLC. Cell biomass for isoprenoid quinone analysis was obtained from culture 
grown in $\mathrm{LB}$ broth for 2 days at $30{ }^{\circ} \mathrm{C}$. Isoprenoid quinones were extracted with chloroform/methanol $(2: 1$, $\mathrm{v} / \mathrm{v})$, evaporated under vacuum conditions and reextracted in $\mathrm{n}$-hexane/water $(1: 1, \mathrm{v} / \mathrm{v})$. The crude quinone in $n$-hexane was purified by using Sep-Pak Vac silica cartridges (Waters) and then analysed by HPLC, as described by Hiraishi et al. (1996). Cellular fatty acids were analysed from cells grown on TSA for $48 \mathrm{~h}$ at $30{ }^{\circ} \mathrm{C}$. The cellular fatty acids were saponified, methylated and extracted according to the protocol of the Sherlock Microbial Identification System (MIDI). The fatty acid methyl esters were then analysed by GC (model 6890; Hewlett Packard) by using the Microbial Identification software package (Sasser, 1990).

Cells of strain $\mathrm{MJ} 3^{\mathrm{T}}$ were Gram-stain-negative, aerobic, motile rods. Colonies grown on LB agar plates for 2 days at $30{ }^{\circ} \mathrm{C}$ were $2-4 \mathrm{~mm}$ in diameter, circular, smooth, convex, shiny, transparent and yellowish. On LB agar, strain $\mathrm{MJ}^{\circ} 3^{\mathrm{T}}$ was able to grow at $20-42{ }^{\circ} \mathrm{C}$, but not at 15 or $45^{\circ} \mathrm{C}$. Normal growth was also observed on R2A agar, TSA and nutrient agar at $20-30{ }^{\circ} \mathrm{C}$ and weak growth occurred on these media at 37 and $42{ }^{\circ} \mathrm{C}$. On MacConkey agar, growth occurred at $20-30{ }^{\circ} \mathrm{C}$, but not at $37^{\circ} \mathrm{C}$. Strain $\mathrm{MJ} 03^{\mathrm{T}}$ and the type strains of five closely related species of the genus Stenotrophomonas (S. acidaminiphila KACC $11356^{\mathrm{T}}$, S. humi DSM $18929^{\mathrm{T}}$, S. nitritireducens KACC $10891^{\mathrm{T}}$, S. terrae DSM $18941^{\mathrm{T}}$ and S. maltophilia KCTC $1773^{\mathrm{T}}$ ), used in this study as reference strains, were positive for catalase, esterase (C4), esterase lipase (C8), naphthol-AS-BI-phosphohydrolase, casein hydrolysis, assimilation of $\mathrm{N}$-acetylglucosamine, L-alanine, L-proline and L-serine, and acid production from cellobiose, D-fructose, D-glucose, lactose, D-mannose and starch. All these strains were negative for cystine arylamidase, $\alpha$-fucosidase, $\alpha$-galactosidase, $\beta$-galactosidase, $\beta$-glucuronidase, lipase (C14) and $\alpha$-mannosidase, indole production, hydrolysis of xylan and HE-cellulose, $\mathrm{H}_{2} \mathrm{~S}$ production, assimilation of adipate, caprate, gluconate, 3-hydroxybenzoate, 4-hydroxybenzoate, itaconate, 2ketogluconate, 5-ketogluconate and phenylacetate, and acid production from a number of sugars (e.g. D-arabinose, L-arabinose, D-fucose and sucrose). These results are in good agreement with previously reported data and supported the affiliation of the new isolate to the genus Stenotrophomonas (Palleroni \& Bradbury, 1993; Finkmann et al., 2000; Assih et al., 2002; Heylen et al., 2007). Phenotypic and chemotaxonomic characteristics that differentiate strain $\mathrm{MJ} 03^{\mathrm{T}}$ from its closest neighbours in the genus Stenotrophomonas are listed in Table 1. In particular, strain $\mathrm{MJ} 03^{\mathrm{T}}$ could be differentiated readily from the above-mentioned species of the genus Stenotrophomonas based on its ability to utilize L-arabinose, Lfucose, D-mannitol, L-rhamnose, D-ribose and D-sorbitol and to produce acid from methyl $\alpha$-D-glucopyranoside.

The 16S rRNA gene sequence of strain $\mathrm{MJ}^{\mathrm{T}}{ }^{\mathrm{T}}$ was a continuous stretch of $1420 \mathrm{bp}$. 16S rRNA gene sequence similarity calculations after a neighbour-joining analysis indicated that the closest relatives of strain $\mathrm{MJ} 03^{\mathrm{T}}$ were $S$. acidaminiphila AMX $19^{\mathrm{T}}(97.9 \%)$, S. humi $\mathrm{R}-32729^{\mathrm{T}}$ (97.1\%), S. nitritireducens $\mathrm{L}^{\mathrm{T}}(96.9 \%)$, S. maltophila ATCC $13637^{\mathrm{T}}(96.8 \%)$ and S. terrae R-32768 ${ }^{\mathrm{T}}(96.7 \%)$. Lower levels of similarity $(<96.5 \%)$ were found with the type strains of all other recognized species in the family Xanthomonadaceae, including $S$. koreensis TR6- $01^{\mathrm{T}}, S$. rhizophila e-p $10^{\mathrm{T}}$ and S. ginsengisoli $\mathrm{DCY} 01^{\mathrm{T}}$. The phylogenetic position of the new isolate, determined by using the various tree-making algorithms (neighbour-joining, maximum-parsimony and maximum-likelihood), revealed that strain $\mathrm{MJ}_{03}{ }^{\mathrm{T}}$ appeared within the genus Stenotrophomonas, joining $S$. acidaminiphila $\mathrm{L}^{\mathrm{T}}$ with moderate bootstrap values of 61,55 and $63 \%$, respectively (Fig. 1). The generally accepted criteria for delineating bacterial species state that strains having a level of DNA-DNA relatedness below $70 \%$ (as measured from hybridization) or showing $16 \mathrm{~S}$ rRNA gene sequence dissimilarity above $3 \%$ are considered to belong to separate species (Wayne et al., 1987; Stackebrandt \& Goebel, 1994; Stackebrandt et al., 2002). In view of this definition, the above data indicate that strain $\mathrm{MJ} 03^{\mathrm{T}}$ can be considered to represent a novel species of the genus Stenotrophomonas. For further verification of the taxonomic position of strain $\mathrm{MJ} 3^{\mathrm{T}}$, DNA-DNA hybridization was performed with its most closely related members of the genus Stenotrophomonas.

DNA-DNA hybridization was performed fluorometrically according to the method of Ezaki et al. (1989), by using photobiotin-labelled DNA probes (Sigma) and microdilution wells (Greiner), with five replications for each sample. The highest and lowest values obtained for each sample were excluded and the means of the remaining three values are quoted as the DNA-DNA relatedness. Strain $\mathrm{MJ} 03^{\mathrm{T}}$ exhibited relatively low levels of DNA-DNA relatedness with respect to $S$. acidaminiphila KACC $11356^{\mathrm{T}}$ (34\%), S. humi DSM $18929^{\mathrm{T}}(19 \%)$, S. nitritireducens KACC $10891^{\mathrm{T}}(15 \%)$, S. maltophila KCTC $1773^{\mathrm{T}}(12 \%)$ and S. terrae DSM $18941^{\mathrm{T}}$ $(11 \%)$, indicating that it is not related to them at the species level (Wayne et al., 1987; Stackebrandt \& Goebel, 1994).

Cellular fatty acid profiles of strain $\mathrm{MJ} 03^{\mathrm{T}}$ and the type strains of phylogenetically related species of the genus Stenotrophomonas are shown in Table 2. All strains contained iso- $\mathrm{C}_{15: 0}$ as the dominant component, and branched fatty acids such as iso- $\mathrm{C}_{11: 0}$ and anteiso- $\mathrm{C}_{15: 0}$, the monounsaturated fatty acid iso- $\mathrm{C}_{17: 1} \omega 9 \mathrm{c}$ and branched 3hydroxyl fatty acids as the other major components. However, some minor qualitative and quantitative differences in fatty acid content could be observed between strain $\mathrm{MJ} 3^{\mathrm{T}}$ and its phylogenetically closest relatives. In particular, strain $\mathrm{MJO3}^{\mathrm{T}}$ could be distinguished based on the presence of a small amount of iso- $\mathrm{C}_{13: 0}$ and by the absence of $\mathrm{C}_{12: 0}$ 3-OH. Strain $\mathrm{MJ}_{03}{ }^{\mathrm{T}}$ contained $\mathrm{Q}-8$ as the predominant ubiquinone. The DNA G $+\mathrm{C}$ content of strain $\mathrm{MJ03}^{\mathrm{T}}$ was $64.7 \mathrm{~mol} \%$. These data are in good agreement with those of other members of the genus Stenotrophomonas (Finkmann et al., 2000; Assih et al., 2002; Wolf et al., 2002; Yang et al., 2006; Heylen et al., 2007). 
Table 1. Differential phenotypic characteristics between strain $M J 03^{\top}$ and its closest phylogenetic neighbours in the genus Stenotrophomonas

Strains: 1 , MJ03 ${ }^{\mathrm{T}}$; 2, S. acidaminiphila KACC $11356^{\mathrm{T}}$; 3, S. humi DSM $18929^{\mathrm{T}}$; 4, S. nitritireducens KACC 10891 ${ }^{\mathrm{T}}$; 5, S. maltophilia KCTC $1773^{\mathrm{T}}$; 6, S. terrae DSM $18941^{\mathrm{T}}$. All data are from the present study except where indicated. All strains are positive for casein hydrolysis but negative for indole and $\mathrm{H}_{2} \mathrm{~S}$ production, and hydrolysis of DNA, HE-cellulose and xylan. In API ID 32 GN, API 20NE (assimilation of carbon sources), API ZYM and API 50CHB tests, all strains showed identical biochemical characteristics except those indicated here (see species description). + , Positive; w, weakly positive; - , negative.

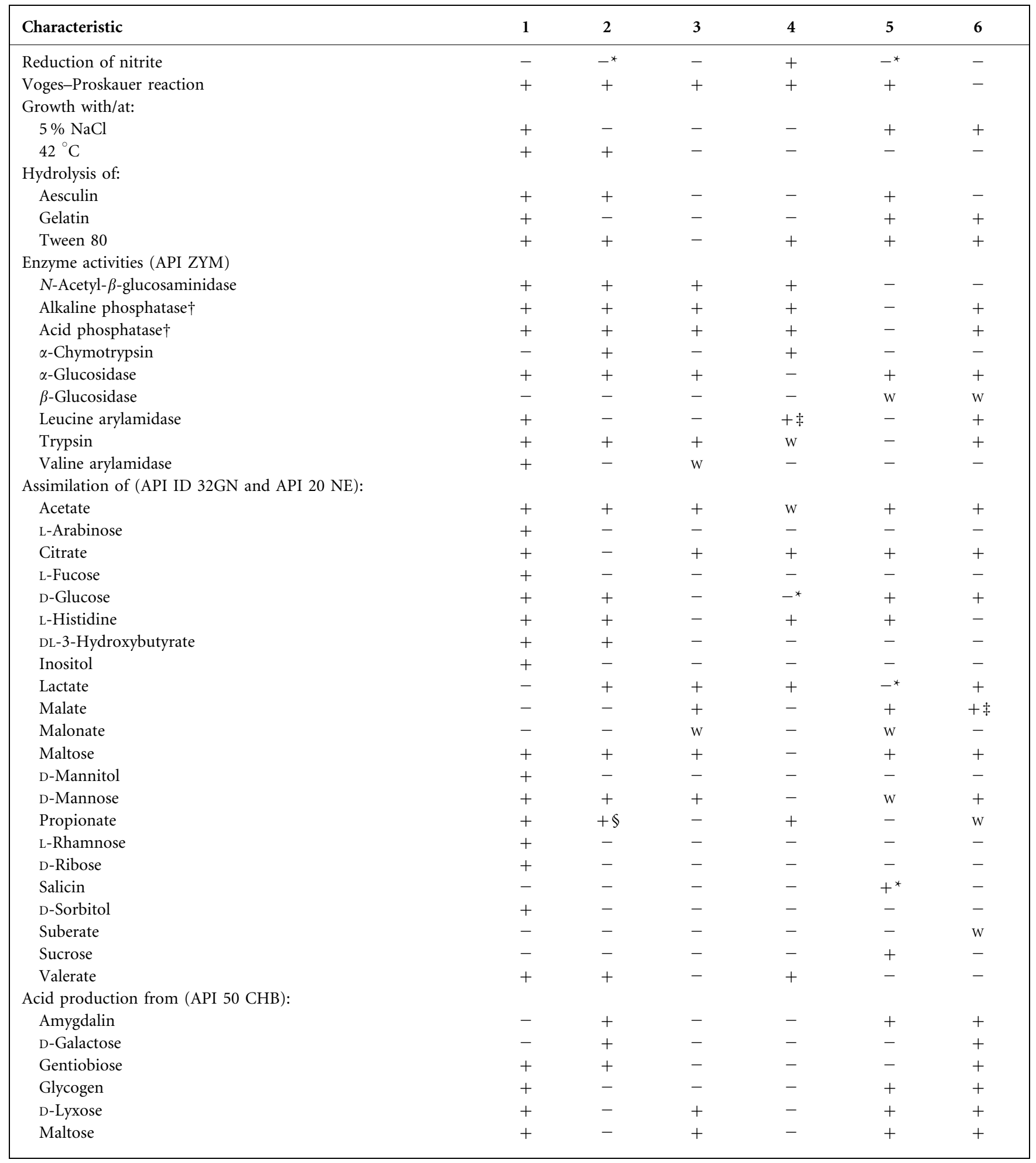


Table 1. cont.

\begin{tabular}{|c|c|c|c|c|c|c|}
\hline Characteristic & 1 & 2 & 3 & 4 & 5 & 6 \\
\hline Melibiose & - & + & - & + & + & + \\
\hline Methyl $\alpha$-D-glucopyranoside & + & - & - & - & - & - \\
\hline Methyl $\beta$-D-xylopyranoside & + & - & - & - & + & - \\
\hline Raffinose & - & - & + & - & + & + \\
\hline D-Ribose & - & + & + & + & - & + \\
\hline Salicin & - & + & - & - & + & + \\
\hline L-Sorbose & - & - & + & - & - & + \\
\hline Trehalose & - & - & - & - & - & + \\
\hline D-Xylose & - & - & + & + & + & + \\
\hline DNA G $+C$ content $(\mathrm{mol} \%)$ & 64.7 & $66.9^{a} \|$ & $64.0^{b}$ & $69.1^{c}$ & $66.7^{c}$ & $65.0^{b}$ \\
\hline
\end{tabular}

${ }^{\star}$ Opposite results were obtained by Yang et al. (2006).

$†$ Same results were obtained using the methods described by Tindall et al. (2007).

$\ddagger$ Opposite results were obtained by Heylen et al. (2007).

$\$$ Opposite result was obtained by Assih et al. (2002).

IIData from: a, Assih et al. (2002); b, Heylen et al. (2007); c, Yoon et al. (2006).

The phenotypic and phylogenetic data presented indicate that strain $\mathrm{MJ} 03^{\mathrm{T}}$ belongs to the genus Stenotrophomonas. The phylogenetic distinctiveness of strain $\mathrm{MJ} 3^{\mathrm{T}}$, together with DNA-DNA hybridization data, confirmed that it represents a species that is distinct from recognized species of this genus. Strain $\mathrm{MJ} 03^{\mathrm{T}}$ can be differentiated from phylogenetically related species of the genus Stenotrophomonas based on several phenotypic characteristics (Table 1). Therefore, on the basis of the data presented, strain $\mathrm{MJ} 03^{\mathrm{T}}$ should be classified within the genus Stenotrophomonas as the type strain of a novel species, for which the name Stenotrophomonas daejeonensis sp. nov. is proposed.

\section{Description of Stenotrophomonas daejeonensis sp. nov.}

Stenotrophomonas daejeonensis (dae.je.on.en'sis. N.L. fem. adj. daejeonensis pertaining to Daejeon, a city in South Korea, from where the type strain was isolated).
Cells are Gram-stain-negative, aerobic, non-spore-forming rods, $0.3-0.4 \mu \mathrm{m}$ in diameter and $1.3-1.6 \mu \mathrm{m}$ in length. After 2 days of incubation at $30{ }^{\circ} \mathrm{C}$ on LB agar, colonies are 2-4 $\mathrm{mm}$ in diameter, circular, smooth, convex, shiny, transparent and yellowish. Grows at $20-42{ }^{\circ} \mathrm{C}$ (optimum, $30{ }^{\circ} \mathrm{C}$ ) and at $\mathrm{pH}$ 6.0-10.0 (optimum, $\mathrm{pH} 7.0-7.5$ ). Nitrate and nitrite are not reduced. Able to hydrolyse aesculin, casein, gelatin and Tween 80 but not HE-cellulose, chitin, starch, xylan or DNA. Positive for the Voges-Proskauer reaction, acid phosphatase, alkaline phosphatase, catalase and oxidase but negative for urease, indole and $\mathrm{H}_{2} \mathrm{~S}$ production. In API ZYM tests, positive for $\mathrm{N}$-acetyl$\beta$-glucosaminidase, esterase (C4), esterase lipase (C8), $\alpha$-glucosidase, leucine arylamidase, naphthol-AS-BIphosphohydrolase, trypsin and valine arylamidase, but negative for $\alpha$-chymotrypsin, cystine arylamidase, $\alpha$-fucosidase, $\alpha$-galactosidase, $\beta$-galactosidase, $\beta$-glucosidase, $\beta$-glucuronidase, lipase (C14) and $\alpha$-mannosidase. In API ID 32 GN and API 20NE tests, utilizes acetate, $\mathrm{N}$-acetylglucosamine, L-alanine, L-arabinose, citrate, L-fucose, D-glucose,

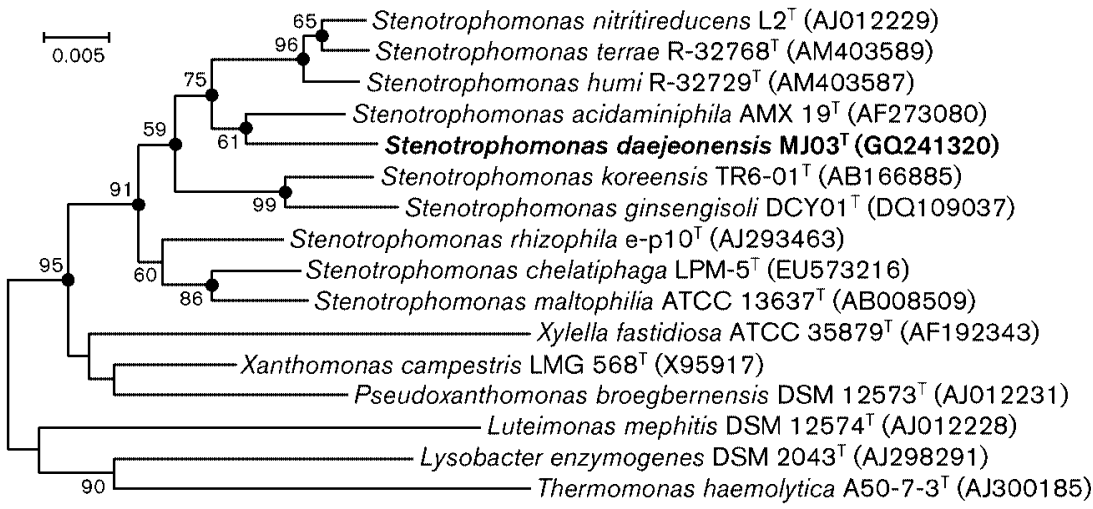

Fig. 1. Neighbour-joining tree, based on $16 \mathrm{~S}$ rRNA gene sequences, showing the phylogenetic position of strain $\mathrm{MJO}^{\top}$ among recognized species of the genus Stenotrophomonas and other related taxa. Bootstrap values (expressed as percentages of 1000 replications) of $>50 \%$ are shown at branch points. Filled circles indicate that the corresponding nodes were also recovered in the tree generated with the maximum-parsimony and maximum-likelihood algorithms. Bar, 0.005 substitutions per nucleotide position. 
Table 2. Cellular fatty acid profiles of strain $\mathrm{MJO}^{\top}$ and its closest phylogenetic neighbours in the genus Stenotrophomonas

Strains: $1, \mathrm{MJ} 3^{\mathrm{T}}$; 2, S. acidaminiphila KACC $11356^{\mathrm{T}}$; 3, S. humi DSM $18929^{\mathrm{T}}$; 4, S. nitritireducens KACC $10891^{\mathrm{T}}$; 5, S. maltophilia KCTC $1773^{\mathrm{T}} ; 6$, S. terrae DSM $18941^{\mathrm{T}}$. All data are from the present study. All strains were grown on TSA at $30{ }^{\circ} \mathrm{C}$ for $48 \mathrm{~h}$ prior to fatty acid analysis. Strain $\mathrm{MJ} 3^{\mathrm{T}}$ and the type strains of $S$. acidaminiphila, $S$. humi and $S$. maltophilia contained small amounts of iso- $\mathrm{C}_{13: 0}$ $(2.1 \%)$, anteiso- $\mathrm{C}_{11: 0}(2.0 \%)$, iso- $\mathrm{C}_{12: 0}(0.9 \%)$ and $\mathrm{C}_{16: 1} \omega 9 c$ $(2.8 \%)$, respectively. Values are percentages of total fatty acids; - , not detected.

\begin{tabular}{|c|c|c|c|c|c|c|}
\hline Fatty acid & 1 & 2 & 3 & 4 & 5 & 6 \\
\hline \multicolumn{7}{|l|}{ Saturated } \\
\hline $\mathrm{C}_{10: 0}$ & - & - & 1.1 & - & - & 1.7 \\
\hline $\mathrm{C}_{14: 0}$ & 1.6 & - & 1.1 & - & 2.7 & 2.5 \\
\hline $\mathrm{C}_{15: 0}$ & 1.6 & - & 1.1 & 2.3 & 1.6 & 1.8 \\
\hline$C_{16: 0}$ & 2.5 & 3.1 & 4.0 & 5.1 & 6.1 & 5.2 \\
\hline iso- $\mathrm{C}_{10: 0}$ & 1.9 & 1.9 & 1.8 & - & - & - \\
\hline iso- $\mathrm{C}_{11: 0}$ & 10.1 & 11.5 & 7.0 & 12.0 & 7.2 & 14.4 \\
\hline iso- $\mathrm{C}_{14: 0}$ & 9.6 & 5.0 & 16.3 & 6.6 & 0.6 & 6.0 \\
\hline iso- $\mathrm{C}_{15: 0}$ & 33.7 & 26.8 & 14.6 & 27.7 & 39.9 & 18.1 \\
\hline iso- $\mathrm{C}_{16: 0}$ & 2.7 & 3.4 & 16.4 & 4.0 & 2.7 & 2.4 \\
\hline anteiso- $\mathrm{C}_{15: 0}$ & 4.2 & 8.6 & 5.4 & 8.4 & 10.1 & 4.7 \\
\hline \multicolumn{7}{|l|}{ Unsaturated } \\
\hline iso- $\mathrm{C}_{15: 1} \mathrm{~F}$ & 4.6 & 4.1 & 1.8 & 5.1 & 2.1 & 5.8 \\
\hline iso- $\mathrm{C}_{17: 1} \omega 9 c$ & 7.3 & 7.9 & 6.3 & 9.6 & 4.9 & 6.7 \\
\hline \multicolumn{7}{|l|}{ Hydroxy } \\
\hline $\mathrm{C}_{12: 0} 3-\mathrm{OH}$ & - & 2.5 & 2.5 & 2.9 & 2.7 & 3.3 \\
\hline $\mathrm{C}_{13: 0} 2-\mathrm{OH}$ & - & 1.9 & - & - & - & 2.1 \\
\hline iso- $\mathrm{C}_{11: 0} 3-\mathrm{OH}$ & 6.4 & 7.6 & 2.2 & 5.9 & 4.3 & 6.5 \\
\hline iso- $\mathrm{C}_{12: 0} 3-\mathrm{OH}$ & 4.1 & 5.1 & 8.5 & 5.1 & 3.1 & 5.7 \\
\hline iso- $\mathrm{C}_{13: 0} 3-\mathrm{OH}$ & 6.1 & 5.6 & 1.7 & 5.3 & 6.2 & 5.9 \\
\hline Summed feature $4^{*}$ & 1.5 & 3.0 & 7.3 & - & 3.0 & 7.2 \\
\hline
\end{tabular}

* Summed features are groups of two or three fatty acids that cannot be separated by GLC with the MIDI system. Summed feature 4 comprised $\mathrm{C}_{16: 1} \omega 7 c$ and/or iso- $\mathrm{C}_{15: 1} 2-\mathrm{OH}$.

L-histidine, DL-3-hydroxybutyrate, inositol, maltose, D-mannitol, D-mannose, L-proline, propionate, L-rhamnose, Dribose, L-serine, D-sorbitol and valerate for growth, but not adipate, caprate, gluconate, glycogen, 3-hydroxybenzoate, 4-hydroxybenzoate, itaconate, 2-ketogluconate, 5-ketogluconate, lactate, malate, malonate, melibiose, phenyl acetate, salicin, suberate or sucrose. In API 50 CHB tests, acid is produced without gas from $\mathrm{N}$-acetylglucosamine, aesculin, cellobiose, D-fructose, gentiobiose, D-glucose, glycogen, lactose, D-lyxose, maltose, D-mannose, methyl $\alpha$-D-glucopyranoside, methyl $\beta$-D-xylopyranoside and starch, but not from adonitol, amygdalin, D-arabinose, L-arabinose, D-arabitol, L-arabitol, arbutin, dulcitol, erythritol, D-fucose, D-galactose, gluconate, inositol, inulin, 2-ketogluconate, 5-ketogluconate, D-mannitol, melezitose, melibiose, methyl $\alpha$-D-mannopyranoside, raffinose, L-rhamnose, D-ribose, salicin, sorbitol, L-sorbose, sucrose, D-tagatose, trehalose, turanose, xylitol,
D-xylose or L-xylose. Q-8 is the predominant ubiquinone. The major cellular fatty acids are iso- $\mathrm{C}_{15: 0}$, iso- $\mathrm{C}_{11: 0}$, iso$\mathrm{C}_{14: 0}$, iso- $\mathrm{C}_{17: 1} \omega 9 c$, iso- $\mathrm{C}_{11: 0} 3-\mathrm{OH}$ and iso- $\mathrm{C}_{13: 0} 3-\mathrm{OH}$. The DNA G + C content of the type strain is $64.7 \mathrm{~mol} \%$.

The type strain, $\mathrm{MJ03}^{\mathrm{T}}\left(=\mathrm{KCTC} 22451^{\mathrm{T}}=\mathrm{JCM} 16244^{\mathrm{T}}\right)$, was isolated from a sewage sample collected from a municipal sewage treatment plant in Daejeon, South Korea.

\section{Acknowledgements}

This work was supported by the Eco-Technopia 21 Project, Ministry of Environment, Republic of Korea (071-081-133).

\section{References}

Assih, E. A., Ouattara, A. S., Thierry, S., Cayol, J.-L., Labat, M. \& Macarie, H. (2002). Stenotrophomonas acidaminiphila sp. nov., a strictly aerobic bacterium isolated from an upflow anaerobic sludge blanket (UASB) reactor. Int J Syst Evol Microbiol 52, 559568.

Atlas, R. M. (1993). Handbook of Microbiological Media. Edited by L. C. Parks. Boca Raton, FL: CRC Press.

Cappuccino, J. G. \& Sherman, N. (2002). Microbiology: a Laboratory Manual, 6th edn. Menlo Park, CA: Benjamin/Cummings.

Collins, C. H. \& Lyne, P. M. (1984). Microbiological Methods, 5th edn. London: Butterworth.

Ezaki, T., Hashimoto, Y. \& Yabuuchi, E. (1989). Fluorometric DNADNA hybridization in microdilution wells as an alternative to membrane filter hybridization in which radioisotopes are used to determine genetic relatedness among bacterial strains. Int J Syst Bacteriol 39, 224-229.

Felsenstein, J. (1981). Evolutionary trees from DNA sequences: a maximum likelihood approach. J Mol Evol 17, 368-376.

Felsenstein, J. (1985). Confidence limit on phylogenies: an approach using the bootstrap. Evolution 39, 783-791.

Felsenstein, J. (2009). PHYLIP (phylogeny inference package), version 3.69. Distributed by the author. Department of Genome Sciences, University of Washington, Seattle, USA.

Finkmann, W., Altendorf, K., Stackebrandt, E. \& Lipski, A. (2000). Characterization of $\mathrm{N}_{2} \mathrm{O}$-producing Xanthomonas-like isolates from biofilters as Stenotrophomonas nitritireducens sp. nov., Luteimonas mephitis gen. nov., sp. nov. and Pseudoxanthomonas broegbernensis gen. nov., sp. nov. Int J Syst Evol Microbiol 50, 273282.

Fitch, W. M. (1971). Toward defining the course of evolution: minimum change for a specific tree topology.

Hall, T. A. (1999). BioEdit: a user-friendly biological sequence alignment editor and analysis program for Windows 95/98/NT. Nucleic Acids Symp Ser 41, 95-98.

Heylen, K., Vanparys, B., Peirsegaele, F., Lebbe, L. \& De Vos, P. (2007). Stenotrophomonas terrae sp. nov. and Stenotrophomonas humi sp. nov., two nitrate-reducing bacteria isolated from soil. Int J Syst Evol Microbiol 57, 2056-2061.

Hiraishi, A., Ueda, Y., Ishihara, J. \& Mori, T. (1996). Comparative lipoquinone analysis of influent sewage and activated sludge by highperformance liquid chromatography and photodiode array detection. J Gen Appl Microbiol 42, 457-469. 
Hsu, S. C. \& Lockwood, J. L. (1975). Powdered chitin agar as a selective medium for enumeration of actinomycetes in water and soil. Appl Microbiol 29, 422-426.

Kim, M. K., Im, W.-T., Ohta, H., Lee, M. \& Lee, S.-T. (2005). Sphingopyxis granuli sp. nov., a beta-glucosidase-producing bacterium in the family Sphingomonadaceae in alpha-4 subclass of the Proteobacteria. J Microbiol 43, 152-157.

Kim, H.-B., Srinivasan, S., Sathiyaraj, G., Quan, L.-H., Kim, S.-H., Bui, T. P. N., Liang, Z.-Q., Kim, Y.-J. \& Yang, D.-C. (2010). Stenotrophomonas ginsengisoli sp. nov., isolated from a ginseng field. Int J Syst Evol Microbiol 60, 1522-1526.

Kimura, M. (1983). The Neutral Theory of Molecular Evolution. Cambridge: Cambridge University Press.

Mesbah, M., Premachandran, U. \& Whitman, W. B. (1989). Precise measurement of the $\mathrm{G}+\mathrm{C}$ content of deoxyribonucleic acid by highperformance liquid chromatography. Int J Syst Bacteriol 39, 159-167.

Moore, D. D. \& Dowhan, D. (1995). Preparation and analysis of DNA. In Current Protocols in Molecular Biology, pp. 2-11. Edited by F. M. Ausubel, R. Brent, R. E. Kingston, D. D. Moore, J. G. Seidman, J. A. Smith \& K. Struhl. New York: Wiley.

Palleroni, N. J. \& Bradbury, J. F. (1993). Stenotrophomonas, a new bacterial genus for Xanthomonas maltophila (Hugh 1980) Swings et al. 1983. Int J Syst Bacteriol 43, 606-609.

Saitou, N. \& Nei, M. (1987). The neighbor-joining method: a new method for reconstructing phylogenetic trees. Mol Biol Evol 4, 406-425.

Sasser, M. (1990). Identification of bacteria through fatty acid analysis. In Methods in Phytobacteriology, pp. 199-204. Edited by Z. Klement, K. Rudolph \& D. C. Sands. Budapest: Akademiai Kaido.

Stackebrandt, E. \& Goebel, B. M. (1994). Taxonomic note: a place for DNA-DNA reassociation and $16 \mathrm{~S}$ rRNA sequence analysis in the present species definition in bacteriology. Int J Syst Bacteriol 44, 846-849.

Stackebrandt, E., Frederiksen, W., Garrity, G. M., Grimont, P. A. D., Kämpfer, P., Maiden, M. C., Nesme, X., Rosselló-Mora, R., Swings, J. $\&$ other authors (2002). Report of the ad hoc committee for the re-evaluation of the species definition in bacteriology. Int J Syst Evol Microbiol 52, 1043-1047.

Tamura, K., Dudley, J., Nei, M. \& Kumar, S. (2007). MEGA4: molecular evolutionary genetics analysis (MEGA) software version 4.0. Mol Biol Evol 24, 1596-1599.

Ten, L. N., Im, W.-T., Kim, M.-K., Kang, M.-S. \& Lee, S.-T. (2004). Development of a plate technique for screening of polysaccharidedegrading microorganisms by using a mixture of insoluble chromogenic substrates. J Microbiol Methods 56, 375-382.

Thompson, J. D., Gibson, T. J., Plewniak, F., Jeanmougin, F. \& Higgins, D. G. (1997). The CLUSTAL_X windows interface: flexible strategies for multiple sequence alignment aided by quality analysis tools. Nucleic Acids Res 25, 4876-4882.

Tindall, J. B., Sikorski, J., Simbert, A. R. \& Krieg, R. N. (2007). Phenotypic characterization and the principles of comparative systematics. In Methods for General and Molecular Microbiology, 3rd edn, pp. 330-393. Edited by C. A. Reddy, T. J. Beveridge, J. A. Breznak, G. A. Marzluf, T. M. Schmidt \& L. R. Snyder. Washington, DC: American Society for Microbiology.

Wayne, L. G., Brenner, D. J., Colwell, R. R., Grimont, P. A. D., Kandler, O., Krichevsky, M. I., Moore, L. H., Moore, W. E. C., Murray, R. G. E. \& other authors (1987). International Committee on Systematic Bacteriology. Report of the ad hoc committee on reconciliation of approaches to bacterial systematics. Int J Syst Bacteriol 37, 463464.

Wolf, A., Fritze, A., Hagemann, M. \& Berg, G. (2002). Stenotrophomonas rhizophila sp. nov., a novel plant-associated bacterium with antifungal properties. Int J Syst Evol Microbiol 52, 1937-1944.

Yang, H.-C., Im, W.-T., Kang, M. S., Shin, D.-Y. \& Lee, S.-T. (2006). Stenotrophomonas koreensis sp. nov., isolated from compost in South Korea. Int J Syst Evol Microbiol 56, 81-84.

Yoon, J.-H., Kang, S.-J., Oh, H. W. \& Oh, T.-K. (2006). Stenotrophomonas dokdonensis sp. nov., isolated from soil. Int J Syst Evol Microbiol 56, 1363-1367. 